\title{
Deciphering the Genetics of Some Important Grain Yield traits in Bread Wheat (Triticum aestivum L. em. Thell)
}

\author{
Kuldeep Nagar ${ }^{1 *}$, Swati $^{2}$, Richa Dhyani ${ }^{2}$ and Deepayan Roy $^{2}$ \\ ${ }^{1}$ Division of Plant Breeding and Genetics, Rajasthan Agricultural Research Institute, \\ Durgapura (Jaipur)-302018, India \\ ${ }^{2}$ Department of Genetics and Plant Breeding, G. B. Pant University of Agriculture and \\ Technology, Pantnagar- 263145 (Uttarakhand), India
}

*Corresponding author

\section{Ke y w o r d s \\ Biparental mating, Diallel, GCA,SCA and Triticum aestivum}

\section{Article Info}

Accepted:

22 June 2020

Available Online:

10 July 2020

\section{A B S T R A C T}

The bread wheat is one of the most important crop providing one-fifth of total calories for world's population. Growth in population is increasing the demand for wheat. Wheat breeders have been concentrated on development of HYV's (High yielding varieties) which required genetic information (mode of inheritance and gene action parameters of yield components) of parental population. For this purpose diallel analysis used. This experiment was carried out with seven wheat genotypes (Triticum aestivumL.) vizHD3159, WAXWING/ /INQALAB91*2/KUKUNA/3/WBLL1*2/ TUKURU/ 8, TACUPETO F2001/ BRAMBLING/ 5/NAC/ TH.AC/ /3*PVN /3/ MIRLO, CROC-1 /AE.SQUARROSA, PASTOR/ / HXL7573/2*BAU /3/ WBLL1/ 6/ MTRWA92.161/ PRINIA/5, WH1080 and PBW660, were used as parents for $7 \times 7$ half-diallel analysis to estimate General Combining Ability (GCA) and Specific Combining Ability (SCA) variances and effects. Genetic analysis indicated that additive variation and non-additive components of genetic variation included dominance and epistatis type gene action and involved in inheritance of all the characters under study. Magnitude of fixable(GCA) components was considerably higher than non fixable component additive variance for all the characters except number of grains per spike representing the predominance of additive gene action. The parents CROC-1/AE.SQUARROSA and TACUPETO F2001/BRAMBLING/5/NAC/TH.AC//3*PVN/3/MIRLO found to be good general combiners for grain yield per plant and most of its component characters and were one of the parents in most of the best specific cross combinations. The WAXWING/ /INQALAB91* 2/KUKUNA /3 / WBLL1 *2/ TUKURU/8 × PASTOR/ /HXL7573 /2*BAU /3 /WBLL1/6/ MTRWA92.161/ PRINIA/5(12.293) and TACUPETO F2001 /BRAMBLING/5 /NAC /TH.AC / /3*PVN/3/ MIRLO × PBW660 (10.249) were the best cross combinations for yield and most of its components. In view of parallel role of both additive and non-additive genetic effects determining the inheritance of different characters, utilization of these variabilty by using biparental mating scheme is suggested. 


\section{Introduction}

As per present growth rate of population, the world population would rise to nearly 9 billion by next two decads. This increasing rate of population responsible for high demand of wheat by $60 \%$ compared with year, 2019. To meet this demand, annual yield of wheat crop have to rise from the current level of $1 \%$ per year to $1.6 \%$ per year until 2050. This problem can be solved by boosting grain yield potential of wheat by developing new wheat cultivars which have desirable genetic makeup and adapt in changing climatic condition (Erkul et al., 2010). Exploring maximum genetic potential from available wheat germplasm is one of the way for achieving this target (Khan et al., 2007). Grain yield is one of the most important trait in wheat breeding, controlled by polygenic gene action so, highly influenced by environmental component of total variation. Since that complimentary combination of yield components may improved the grain yield.

Wheat breeders have been focused on developing varieties with high yield potential, through crossing of germplasm lines have high GCA, average performance of a strain in a series of cross combinations and selecting wanted transgressive segregants for grain yield and yield attibuting traits (Istipliler et al., 2015; Kumar et al., 2015a). Knowledge regarding general and specific combining ability of wheat genotypes, mode of inheritance and gene action parameters of the yield contributing traits helpful to select genetically suitable parents for developing desirable genotypes within its segregating population and could enhance ability for better selection of breeding methods. Diallel analysis method can be used for selection of lines with good genetic makeup and further used for crossing programme as parents (Kohan and Heidari, 2014). The most commonly used diallel techniques for combining ability analysis is Griffing numerical approach (1956) because, it provides information about nature and magnitude of the gene action involved in the inheritance of characters well as valuable information about the combining ability of parents to transmit desirable traits to their progenies (Seboka et al., 2009).Mode of inheritance, combining ability and type of gene action of the yield contributing traits in a full diallel cross of common bread wheat varieties have been analysed by several wheat breeders (Nazir et al., 2014, Yao et al., 2014, Ljubičić et al., 2014, Kumar et al., 2015 and Shehzad et al., 2015). The main objective of wheat breeding program is higher yield. In this study, 7bread wheat genotypes parental line and their half diallel crosses were taken to determine the general and specific combining abilities of selected wheat genotypes and to estimate type gene action involved and mode of inheritance for the traits involved.

\section{Materials and Methods}

This study was carried out at Norman E. Borlaug Crop Research Institute of the G.B. Pant University of Agriculture and Technology, Pantnagar (Uttarakhand), India during the Rabi seasons of 2017/18 and 2018/19. The experimental material comprised of seven wheat genotypes (Triticum aestivumL.) viz- HD3159, WAXWING/ / INQALAB91*2/ KUKUNA/3/ WBLL1*2/ TUKURU/ 8, TACUPETO F2001/ BRAMBLING/ 5/NAC/ TH.AC/ /3*PVN /3/ MIRLO, CROC-1 /AE.SQUA RROSA, PASTOR/ / HXL 7573/2*BAU /3/ WBLL1/ 6/ MTRWA92.161/ PRINIA/5, WH1080 and PBW660 in this study (Table1). These genotypic lines were crossed in half diallel fashion $(7 \times 7)$, through hand emasculation and hand pollination, because reciprocal differences are not significant in 
case of wheat crop and the first filial generation was obtained. The genotypes were sown in 2 rows of $1 \mathrm{~m}$ long each, with $20 \mathrm{~cm}$ of inter-row spacing in a RBD, Randomized Block Design in three replications. The observation for considered traits were taken on 5 plants/replication at maturity stage of crop, i.e. Number of grains per spike, 1000 grain weight, Grain yield per plant $(\mathrm{g})$ and Harvest index of wheat crop. General combining ability (GCA) and specific combining ability (SCA) were analyzed following Model 1, Method 2 (includes parents and $F_{1}$ crosses excluding reciprocals) of the numerical approach of diallel analyses given by Griffing (1956) The components of genetic variance were calculated according to formula given by Hayman (1954) and Mather and Jinks (1971).

\section{Results and Discussion}

\section{Performance of wheat genotypes}

The present study observed that TACUPETO F2001/ BRAMBLING/5/NAC/ TH.AC/ /3*PVN/3/ MIRLO has highest mean average value for number of grains per spike $(56.222$ g) while the lowest mean value $(42.083 \mathrm{~g})$ observed for parent WH1080. Among the $\mathrm{F}_{1}$ 's, maximum mean value was observed in cross WAXWING/ /INQALAB91*2/
KUKUNA/3/ WBLL1*2/ TUKURU /8 $\times$ TACUPETO F2001/ BRAMBLING / 5/NAC/TH.AC/ / 3*PVN/3/ MIRLO (60.384 $\mathrm{g})$ followed with crosses HD3159×XWH1080 (59.011 g) (Table2). Minimum mean value for $\mathrm{F}_{1}$ crosses was recorded in the cross combination CROC1/AE.SQUARROSA $\times$ WH1080 (40.778 g), followed with cross PASTOR/ / HXL7573/2*BAU/3/WBLL1/6/

MTRWA92.161/PRINIA/5 $\times$ PBW660 (41.956 g). For 1000 grain weight, superior mean value (53.233 g) was shown by the parent CROC-1/AE.SQUARROSA against the lowest $(45.933 \mathrm{~g})$ by the parent PASTOR/ /HXL7573/2*BAU/ 3/ WBLL1/ 6/ MTRWA92.161/ PRINIA /5 (Table2). Among cross combinations the greatest mean value was observed in cross combination HD3159 × PASTOR/ /HXL7573/2 *BAU/ 3/WBLL1/ 6/ MTRWA92.161/ PRINIA /5 $(57.767 \mathrm{~g})$, followed with cross combinations TACUPETO F2001/ BRAMBLING/ 5/ NAC/ TH.AC/ /3*PVN/3/ MIRLO× PBW660 $(55.333 \mathrm{~g})$ (Table2). The lowest mean value $(43.243 \mathrm{~g})$ was recorded in cross combinations PASTOR/ /HXL7573/2*BAU /3/ WBLL1/6/ MTRWA92.161/ PRINIA /5 × WH1080 followed by WAXWING/ /INQALAB91*2/ KUKUNA /3/ WBLL1*2 / TUKURU /8 × WH1080 (43.333 g) (Table 2)

Table.1 The bread wheat genotypes used as parental genotypes for producing first filial generation $\left(\mathrm{F}_{1}\right)$

\begin{tabular}{|l|l|}
\hline $\mathbf{S . N}$. & \multicolumn{1}{|c|}{ Genotypes } \\
\hline $\mathbf{1}$ & HD3159 \\
\hline $\mathbf{2}$ & WAXWING/ /INQALAB91*2/KUKUNA/3/WBLL1 $* 2 / T U K U R U / 8$ \\
\hline $\mathbf{3}$ & TACUPETO F2001/BRAMBLING/5/NAC/TH.AC/ /3*PVN/3/MIRLO \\
\hline $\mathbf{4}$ & CROC-1/AE.SQUARROSA \\
\hline $\mathbf{5}$ & PASTOR//HXL7573/2*BAU/3/WBLL1/6/MTRWA92.161/PRINIA/5 \\
\hline $\mathbf{6}$ & WH1080 \\
\hline $\mathbf{7}$ & PBW660 \\
\hline
\end{tabular}


Table.2 Parents and $\mathrm{F}_{1}$ 's (7x7half diallel cross) with Mean values of characters

\begin{tabular}{|c|c|c|c|c|}
\hline \multirow[t]{2}{*}{ Genotypes } & \multicolumn{4}{|c|}{ Characters } \\
\hline & \multirow[t]{2}{*}{ Grains/Spike } & \multirow{2}{*}{$\begin{array}{l}1000 \\
\text { grain } \\
\text { weight }\end{array}$} & \multirow{2}{*}{$\begin{array}{l}\text { Grain } \\
\text { yield/Plant }\end{array}$} & \multirow{2}{*}{$\begin{array}{l}\text { Harvest } \\
\text { index }\end{array}$} \\
\hline Parents & & & & \\
\hline HD3159 & 46.221 & 46.410 & 23.753 & 47.185 \\
\hline WAXWING/ / INQALAB91*2/KUKUNA/3/ WBLL1 $* 2$ / TUKURU /8 & 45.521 & 51.233 & 23.782 & 34.311 \\
\hline TACUPETO F2001/ BRAMBLING/5/NAC/TH.AC/ /3*PVN/3/ MIRLO & 56.222 & 49.267 & 33.367 & 50.685 \\
\hline CROC-1/AE.SQUARROSA & 50.968 & 53.233 & 38.693 & 40.190 \\
\hline PASTOR//HXL7573/2*BAU /3/ WBLL1/6/MTRWA92.161/PRINIA/5 & 54.163 & 45.933 & 25.233 & 33.390 \\
\hline WH1080 & 42.083 & 46.233 & 27.547 & 51.687 \\
\hline PBW660 & 43.052 & 48.667 & 26.987 & 50.678 \\
\hline \multicolumn{5}{|l|}{ Crosses } \\
\hline $\begin{array}{l}\text { HD3159 } \times \text { WAXWING/ / INQALAB91*2/KUKUNA/3/ WBLL1*2/ } \\
\text { TUKURU/8 }\end{array}$ & 46.667 & 51.333 & 30.747 & 45.327 \\
\hline $\begin{array}{l}\text { HD3159 } \times \text { TACUPETO F2001 /BRAMBLING/5/NAC/ TH.AC/ } \\
\text { /3*PVN/3/MIRLO }\end{array}$ & 54.733 & 52.600 & 35.473 & 42.454 \\
\hline HD3159 × CROC-1/AE.SQUARROSA & 54.900 & 54.100 & 33.783 & 45.347 \\
\hline $\begin{array}{l}\text { HD3159 } \times \text { PASTOR/ /HXL7573/2*BAU/3/WBLL1/ 6/ MTRWA92.161/ } \\
\text { PRINIA/5 }\end{array}$ & 43.676 & 57.767 & 24.610 & 38.474 \\
\hline HD3159 $\times$ WH1080 & 59.011 & 48.400 & 34.243 & 57.570 \\
\hline HD3159 $\times$ PBW660 & 54.444 & 50.767 & 31.923 & 59.254 \\
\hline $\begin{array}{l}\text { WAXWING/ /INQALAB91*2 /KUKUNA/3/WBLL1 } * 2 / \text { TUKURU/8 } \times \\
\text { TACUPETO F2001 / BRAMBLING/ 5/ NAC/TH.AC/ /3*PVN/3/MIRLO }\end{array}$ & 60.384 & 50.267 & 32.743 & 52.249 \\
\hline $\begin{array}{l}\text { WAXWING/ /INQALAB91* 2/KUKUNA/3/WBLL1* 2/TUKURU/8 } \times \\
\text { CROC-1/ AE.SQUARROSA }\end{array}$ & 57.681 & 51.100 & 40.303 & 44.416 \\
\hline $\begin{array}{l}\text { WAXWING/ /INQALAB91* 2/KUKUNA/3/WBLL1 } * 2 / \text { TUKURU/8 } \times \\
\text { PASTOR/ /HXL7573/ } 2 * \text { BAU/3/ WBLL1/6/ MTRWA92.161/PRINIA/5 }\end{array}$ & 47.806 & 45.167 & 42.123 & 56.572 \\
\hline $\begin{array}{l}\text { WAXWING/ /INQALAB91*2/KUKUNA/3/ WBLL1*2/TUKURU/8 × } \\
\text { WH1080 }\end{array}$ & 55.858 & 43.333 & 34.467 & 49.147 \\
\hline $\begin{array}{l}\text { WAXWING//INQALAB91*2/KUKUNA/3/WBLL1*2/TUKURU/8 } \times \\
\text { PBW660 }\end{array}$ & 51.556 & 54.500 & 30.530 & 52.501 \\
\hline $\begin{array}{l}\text { TACUPETO F2001/BRAMBLING/5/NAC/TH.AC/ /3*PVN/3/ MIRLO } \\
\times \text { CROC-1/AE.SQUARROSA }\end{array}$ & 49.778 & 46.200 & 25.923 & 39.934 \\
\hline $\begin{array}{l}\text { TACUPETO F2001/ BRAMBLING/5/ NAC/TH.AC/ /3*PVN/3/MIRLO } \\
\times \text { PASTOR//HXL7573/2*BAU/3/ WBLL1/6/ MTRWA92.161/ } \\
\text { PRINIA/5 }\end{array}$ & 50.889 & 50.900 & 27.735 & 43.373 \\
\hline $\begin{array}{l}\text { TACUPETO F2001/ BRAMBLING/5/NAC/TH.AC/ /3*PVN/3/ MIRLO } \\
\times \text { WH1080 }\end{array}$ & 50.889 & 52.300 & 34.553 & 48.773 \\
\hline $\begin{array}{l}\text { TACUPETO F2001/BRAMBLING/5/NAC/TH.AC/ /3*PVN/3/ MIRLO } \times \\
\text { PBW66 }\end{array}$ & 57.889 & 55.333 & 42.977 & 54.106 \\
\hline $\begin{array}{l}\text { CROC-1/AE.SQUARROSA } \times \text { PASTOR/ } \\
\text { /HXL7573/2*BAU/3/WBLL1/6/MTRWA92.161/ PRINIA/5 }\end{array}$ & 43.000 & 54.033 & 32.447 & 40.268 \\
\hline CROC-1/AE.SQUARROSA $\times$ WH1080 & 40.778 & 52.333 & 43.622 & 49.773 \\
\hline CROC-1/AE.SQUARROSA $\times$ PBW660 & 53.889 & 54.267 & 40.860 & 47.727 \\
\hline $\begin{array}{l}\text { PASTOR//HXL7573/2*BAU/3/ WBLL1/6/MTRWA92.161/PRINIA/5 } \times \\
\text { WH1080 }\end{array}$ & 51.556 & 43.243 & 32.593 & 41.625 \\
\hline $\begin{array}{l}\text { PASTOR//HXL7573/2*BAU/3/WBLL1/6/MTRWA92.161/PRINIA/5 × } \\
\text { PBW660 }\end{array}$ & 41.956 & 49.600 & 26.407 & 33.494 \\
\hline WH1080 $\times$ PBW660 & 47.444 & 53.233 & 28.130 & 42.040 \\
\hline
\end{tabular}


Table.3 Mean squares values (MS) from combining ability analysis for the analyzed traits in $7 \times 7$ diallel cross of wheat

\begin{tabular}{|l|l|l|l|l|l|}
\hline \multirow{2}{*}{$\begin{array}{l}\text { Source } \\
\text { variation }\end{array}$} & of & DF & \multicolumn{4}{|c|}{ Mean Square (MS) } \\
\hline GCA & & Grains/spike & 1000 grain weight & Grain yield/plant & Harvest index \\
\hline SCA & 6 & $32.344^{* *}$ & $15.956^{* *}$ & $42.049^{* *}$ & $77.058^{* *}$ \\
\hline Error & 21 & $33.129^{* *}$ & $13.358^{* *}$ & $34.124^{* *}$ & $42.256^{* *}$ \\
\hline GCA/SCA & 54 & 7.260 & 0.130 & 0.506 & 1.830 \\
\hline
\end{tabular}

Grains $/$ spike $=$ Number of grains per spike, $\mathrm{DF}=$ Degree of freedom

Table.4 Estimates of general combining ability (GCA) effects for the analyzed traits in a $7 \times 7$

diallel cross of bread wheat

\section{Genotypes}

Parents

\begin{tabular}{|l|l|l|l|l|}
\hline HD3159 & $\begin{array}{l}\text { Grains/ } \\
\text { spike }\end{array}$ & $\begin{array}{l}1000 \\
\text { grain } \\
\text { weight }\end{array}$ & $\begin{array}{l}\text { lield/ } \\
\text { plant }\end{array}$ & $\begin{array}{l}\text { index } \\
\text { ind }\end{array}$ \\
\hline WAXWING//INQALAB91*2/KUKUNA/3/WBLL1*2/TUKURU/8 & 0.239 & $0.492^{* *}$ & $-2.271 * *$ \\
$0.499 * *$
\end{tabular}

** = Highly Singificant and GCA = General Combining Ability

Table.5 Estimates of specific combining abilities (SCA) effects for the analyzed traits in a $7 \times 7$ diallel cross of bread wheat

\begin{tabular}{|c|c|c|c|c|}
\hline \multirow[t]{2}{*}{ Crosses } & \multicolumn{4}{|c|}{ SCA Values } \\
\hline & $\begin{array}{l}\text { Grains/ } \\
\text { spike }\end{array}$ & $\begin{array}{l}1000 \\
\text { grain } \\
\text { weight }\end{array}$ & $\begin{array}{l}\text { Grain } \\
\text { yield/ } \\
\text { plant }\end{array}$ & $\begin{array}{c}\text { Harvest } \\
\text { index }\end{array}$ \\
\hline $\begin{array}{l}\text { HD3159 } \\
\text { WAXWING//INQALAB91*2/KUKUNA/3/WBLL } \\
1 * 2 / \text { TUKURU/8 }\end{array}$ & $-4.846 * *$ & $0.998 * *$ & $0.705^{*}$ & $-2.283 * *$ \\
\hline $\begin{array}{l}\text { HD } 3159 \times \text { TACUPETO F2001/ BRAMBLING / } \\
\text { 5/ NAC/ TH.AC/ /3*PVN /3 / MIRLO }\end{array}$ & 0.330 & $1.380 * *$ & $4.580 * *$ & $-6.648 * *$ \\
\hline HD3159 $\times$ CROC-1/AE.SQUARROSA & $4.390 * *$ & $1.506 * *$ & -0.241 & 0.069 \\
\hline $\begin{array}{l}\text { HD } 3159 \times \text { PASTOR / / HXL7573 /2*BAU / 3/ } \\
\text { bWBLL1 /6 / MTR WA 92.161 / PRINIA /5 }\end{array}$ & $-5.194 * *$ & $8.053 * *$ & $-2.977 * *$ & $-3.775 * *$ \\
\hline HD3159 $\times$ WH1080 & $9.864 * *$ & $-0.506 * *$ & $3.732 * *$ & $7.352 * *$ \\
\hline HD3159 $\times$ PBW660 & $4.900 * *$ & $-1.442 * *$ & $2.290 * *$ & $9.239 * *$ \\
\hline
\end{tabular}




\begin{tabular}{|c|c|c|c|c|}
\hline $\begin{array}{l}\text { WAXWING / /INQALAB91 *2 / KUKUNA /3/ } \\
\text { WBLL1 } * 2 \text { / TUKURU / } 8 \times \text { TACUPETO F 2001/ } \\
\text { BRAMBLING / 5/ NAC/ TH.AC/ / 3* PVN/3/ MI } \\
\text { RLO }\end{array}$ & $5.413 * *$ & 0.115 & -0.393 & $4.698 * *$ \\
\hline $\begin{array}{l}\text { WAXWING / /INQALAB91 } * 2 / \text { KUKUNA } / 3 / \\
\text { WBLL1 } * 2 \text { / TUKURU /8 } \times \text { CROC-1 / AE. } \\
\text { SQUARROSA }\end{array}$ & $6.603 * *$ & $-0.425^{*}$ & $4.035^{* *}$ & 0.689 \\
\hline $\begin{array}{l}\text { WAXWING/ /INQALAB91* 2/KUKUNA /3 / } \\
\text { WBLL1 } * 2 / \text { TUKURU/8 } \times \text { PASTOR/ /HXL7573 } \\
\text { /2*BAU /3 /WBLL1/6/ MTRWA92.161/ PRINIA/5 }\end{array}$ & -1.633 & $-3.478 * *$ & $12.293 * *$ & $15.874 * *$ \\
\hline $\begin{array}{l}\text { WAXWING/ /INQALAB91*2 KUKUNA /3 / } \\
\text { WBLL1 } * 2 / \text { TUKURU } / 8 \times \text { WH1080 }\end{array}$ & $6.142 * *$ & $-4.504 * *$ & $1.712 * *$ & 0.481 \\
\hline $\begin{array}{l}\text { WAXWING//INQALAB91*2/KUKUNA/3/WBLL } \\
1 * 2 / \text { TUKURU/8 } \times \text { PBW660 }\end{array}$ & 1.442 & $3.360 * *$ & $-1.347 * *$ & $4.037 * *$ \\
\hline $\begin{array}{l}\text { TACUPETO F2001 / BRAMBLING / } 5 \text { / NAC } \\
\text { /TH.AC/ /3* PVN/3/ MIRLO } * \text { CROC-1/ } \\
\text { AE.SQUARROSA }\end{array}$ & $-4.190 * *$ & $-6.210 * *$ & $-11.196 * *$ & $-5.284 * *$ \\
\hline $\begin{array}{l}\text { TACUPETO F2001/BRAMBLING /5 / NAC/ } \\
\text { TH.AC/ /3*PVN/3/ MIRLO × PASTOR / / } \\
\text { HXL7573/ } 2 * \text { BAU /3/ WBLL1 /6/ MTRWA92.161 } \\
\text { / PRINIA/5 }\end{array}$ & -1.440 & $1.370 * *$ & $-2.946^{*}$ & 1.184 \\
\hline $\begin{array}{l}\text { TACUPETO } \\
\text { 5/NAC/TH.AC/ /3*PVN/3/ MIRLO } \times \text { WH1080 }\end{array}$ & -1.717 & $3.577 * *$ & $0.948 * *$ & $-1.385^{*}$ \\
\hline $\begin{array}{l}\text { TACUPETO F2001 /BRAMBLING/5 /NAC } \\
/ \text { TH.AC / /3*PVN/3/ MIRLO } \times \text { PBW660 }\end{array}$ & $4.885 * *$ & $3.308 * *$ & $10.249 * *$ & $4.150 * *$ \\
\hline $\begin{array}{l}\text { CROC-1 IAE.SQUARROSA } \quad \text { PASTOR/ } \\
\text { /HXL7573/2*BAU/3/ WBLL1 /6 / MTRWA92.161/ } \\
\text { PRINIA /5 }\end{array}$ & $-5.435 * *$ & $3.129 * *$ & $-1.366 * *$ & $1.901 * *$ \\
\hline CROC-1/AE.SQUARROSA $\times$ WH1080 & $-7.934 * *$ & $2.236^{* *}$ & $6.884 * *$ & $3.438 * *$ \\
\hline CROC-1/AE.SQUARROSA $\times$ PBW660 & $4.779 * *$ & $0.867 * *$ & $5.001 * *$ & $1.595 *$ \\
\hline $\begin{array}{l}\text { PASTOR//HXL7573/2*BAU/3/WBLL1/6/MTRW } \\
\text { A92.161/PRINIA/5 } \times \text { WH1080 }\end{array}$ & $4.483 * *$ & $-3.973 * *$ & $2.294 * *$ & $-1.680 *$ \\
\hline $\begin{array}{l}\text { PASTOR//HXL7573/2*BAU/3/WBLL1/6/MTRW } \\
\text { A92.161/PRINIA/5 } \times \text { PBW66 }\end{array}$ & $-5.515 * *$ & $-0.919 *$ & $-3.015 * *$ & $-9.609 * *$ \\
\hline WH1080 $\times$ PBW660 & -0.303 & $3.522 * *$ & $-4.216^{* *}$ & $-9.031 * *$ \\
\hline
\end{tabular}

Analysis of Variance (ANOVA)

The analysis of variance for number of kernels/spike, 1000-kernel weight, grain yield per plant and harvest index are presented in Table 3. The results reflected significant differences among mean squares due to general combining ability (GCA) and specific combining ability (SCA) for all the characters under study. The analysis of combining ability revealed that variance associated with general and specific combining ability reached the level of significance for all studied characters. The variances ratio due was less than unity for all the traits under study, which reflect the importance of nonadditive types of gene actions in the expression of characters. These results are in 
agreement with those obtained by Burungale et al., (2011) and Mandal et al., (2016) in wheat crop and Roy et al., (2019) in rice.

However, general combining ability effects which were extremely of high magnitude suggested the predominant role of additive gene action. This result supported by the over unity of GCA and SCA values, indicating that additively play a considerable role in the inheritance of these characters. Therefore, selection in the early generation could be successfully practiced to improve these characters.

These results were agreed with those reported by Bhuttaet al., (1997), Abd El-Atyand Hamad (2006), Kumar et al., (2011), Barotet al., (2014) and Farooq et al., (2019) in wheat crop.

\section{General combining ability (GCA)}

Estimates of general combining ability effects for each parent are presented in table 4. High positive values would be of great interest in all studied characters under investigation. Results indicated that the cultivar TACUPETO F2001/BRAMBLING /5/NAC/TH.AC/ /3* PVN/3/ MIRLO (3.698) proved to be a good general combiner for number of grains per spike followed by PASTOR/

/HXL7573/2*BAU/3//6 /MTRWA92.161/ PRINIA/5 (1.834), WAXWING/ /INQALAB91*2/ KUKUNA/3/ WBLL1*2/ TUKURU /8 (0.808) and HD3159 (0.239) but the other three parents exhibited negative GCA effects for this character (Table 4). CROC1/AE.SQUARROSA (1.682) found to be good general combiner for 1000 grain weight followed by PBW660 (1.297), HD3159 (0.492) and TACUPETO F2001/ BRAMBLING/ 5/ NAC/ TH.AC/ /3*PVN/3/ MIRLO (0.308). In case of grain yield per plant CROC-1 /AE.SQUARROSA (3.954) proved to be good general combiner followed by TACUPETO F2001/ BRAMBLING /5/ NAC/TH.AC/ /3*PVN / 3/MIRLO (0.823). For harvest index PASTOR/ /HXL7573/2* BAU/ 3/WBLL1/ 6/ MTRWA92.161/ PRINIA /5 (5.412) parental genotype found to be good general combiner followed by WH1080 (2.555) and PBW660 (2.352) (Table 4).

Since in breeding program higher values of number of grains per spike, 1000 grain weight, grain yield per plant and harvest index was considered, therefore positive GCA effects are preferred for these traits. In this view, parents TACUPETO F2001/ BRAMBLING/5/NAC/TH.AC/ /3*PVN/3/ MIRLO showed significant positive general combining ability for all studied characters. Moreover, the cultivar HD3159, showed significant general combining ability effects for all the characters except, grain yield per plant is considered best for improving traits, because they showed the highest positive values of GCA for maximum number of traits (Table 4).The crosses involving these good general combining ability genotypes as parents should produce promising progeny segregation generation with higher mean performance of those character. Consequently, the results of the average performance of the respective characters are in agreement with those reported by Singh and Paroda (1986), Mohamed (2007), Cifi and Yagdi (2010), Kumar et al., (2011), Aida Rizkalla et al., (2012) Ashraf et al., (2015) and Farooq et al., (2019) in wheat crop. High values of General Combining Ability (GCA) in positive direction indicated that most of the characters is contolled by heritable and fixable companents of gene action (Additive effect or/and Additive $\times$ Additive interaction effects) genotypes, can be utilized for the improvement of concerned traits, selection in early segregating generations would be effective for these characters. 
The crosses which displayed good specific cross combination for these yield traits were obtained from parents with various types of general combiner $($ good $\times$ good, good $\times$ average, good $\times$ poor, average $\times$ average, average $\times$ poor and poor $\times$ poor general combiner). The highest significant positive SCA effect for grains/spike was observed for cross HD3159 $\times$ WH1080 (average $\times$ poor general combiner) (9.864), followed by crosses WAXWING/ /INQALAB91*2/KUKUNA/ 3/WBLL1 $* 2 /$ TUKURU/8 $\times$ CROC-1/AE.SQUARROSA (average $\times$ poor general combiner) (6.603), WAXWING / /INQALAB91*2/ KUKUNA/3/ WBLL1 $* 2 /$ TUKURU/ $8 \times$ WH1080 (average $\times$ poor general combiner) (6.142) (Table 5). In case of 1000 grain weight, cross TACUPETO F2001/ BRAMBLING/ 5/NAC/ TH.AC/ /3*PVN/3/MIRLO $\times$ WH1080 $($ good $\times$ poor general combiner) (8.577) followed by HD3159 × PASTOR/ /HXL7573/2*BAU/3 /WBLL1/6/ MTRWA92.161/PRINIA/5 (good $\times$ poor general combiner) (8.053) and WH1080 $\times$ PBW660 (poor $\times$ good general combiner) showed highest significant sca effects (Table 5). For grain yield per plant cross WAXWING/ /INQALAB91*2 /KUKUNA/3/ WBLL1 $* 2 /$ TUKURU/8 $\times$ PASTOR/ /HXL7573/2*BAU/3/WBLL1/6/ MTRWA92.161/PRINIA/5 (poor $\times$ poor general combiner) (12.293) TACUPETO F2001/BRAMBLING /5/NAC/TH.AC/ /3*PVN/3/ MIRLO $\times$ PBW660 $(\operatorname{good} \times$ poor general combiner) (10.249) and CROC1/AE.SQUARROSA $\times$ WH1080 $(\operatorname{good} \times$ poor general combiner (6.884) found best cross combinations while, in case harvest index cross HD3159 $\times$ PBW660 (poor $\times$ poor) (2.290) followed by HD3159 $\times$ WH1080 (good $\times$ good general combiner) (3.732) and WAXWING/ /INQALAB91*2/ KUKUNA/3/ WBLL $1 * 2 / \quad$ TUKURU/8 $\times$ PASTOR/ /HXL7573/2*BAU/3/ WBLL1/6/ MTRWA 92.161/PRINIA/5 (good $\times$ good general combiner) (12.293) were good cross combinations (Table 5). Greater SCA effects obtained from parents with various types of GCA effects has been also reported by Raj and Kandalkar (2013) and Bagiu and Nedelea (2013), Kohan and Heidari (2014) and Kumar et al., (2018) in wheat crop. It was also observed that some crosses showed poor specific combiners, although parents involved in these cross combinations were good general combiners. Now it is clear that parents with high GCA effect always might not produced progenies which possess high value SCA effects.

Two crosses (TACUPETO F2001/ BRAMBLING/5/NAC/ TH.AC/ $/ 3 * \mathrm{PVN} / 3 /$ MIRLO $\times$ PBW660 and CROC-1/AE.SQUA RROSA $\times$ PBW660) were found good specific combiner for all the four characters i.e. number of grains per spike, 1000 grain weight, grain yield per plant and harvest index while four cross $(\mathrm{HD} 3159 \times$ CROC1/AE.SQUARROSA) found to be good specific combiner for number of grains per spike, 1000 grain weight and grain yield per plant. Two crosses namely, HD3159 $\times$ WH1080 and HD3159 × PBW660 have good cross combinations of four three traits (number of grains per spike, grain yield per plant and harvest index) (Table 5). SCA effect is indication of the dominance and epistatic type gene interactions, not significantly useful in self-pollinated crops improvement as wheat.Specific Combining Ability (SCA) is useful for cross fertilizing crop improvement (Istipliler et al., (2015) and Farooq et al., (2019), in selecting the homozygous lines (transgressive segregants) in segregating generations and in exploitation of heterosis in sexually propagated crops, where nonadditive companents of gene action could be utilized. additive variance is main factor, decide the success of any selection programme. The crosses, obtained from parents with high GCA effects can be utilized further viz-HD3159 $\times$ WH1080 and 
WAXWING/ /INQALAB91*2/KUKUNA /3 /WBLL1*2/TUKURU/8 $\times$ PASTOR/ /HXL7573/2* BAU/ 3/WBLL1/6/ MTRWA 92.161 / PRINIA/5 could be utilized in breeding programs for development of superior stains. These genotypes have fixable component (additive $\times$ additive type of epistatic interaction) which get fixed in later generations and can be used in future plant breeding. Cross with greater SCA effects for harvest index showed possibility of genetic improvement through pedigree method of selection. In case of self pollinated crops importance of greater SCA effects in crosses which involved both parents with high GCA.

For grain yield per plant, greater SCA effects obtained in crosses, involving one parent with good and other with poor general combiner are the results of additive $\times$ dominance type gene interaction for expression of character (TACUPETO F2001/ BRAMBLING/5/ NAC/TH.AC/ / $3 *$ PVN/3 /MIRLO $\times$ PBW660 (10.249) and CROC-1/AE.SQUARROSA $\times$ WH1080). Although both parents involved in cross have poor general combining ability but they produced progeny (HD3159 $\times$ PBW660), with good SCA effects. It proves that promising combinations could be also obtained from crossing of genotypes with low GCA. These results obtained due to the presence of non-allelic interaction (unfixable components) at heterozygous loci, single plant selection in the later generations is one of the best way of utilizing of these genotypes. In parental lines which involve both parents with poor general combiner, compared with parents of high GCA, heterozygous were highly sensitive to the environmental conditions due to nonadditive effects (dominance and epistasis interaction). In cross pollinated species more of contribution of dominance non-additive effects could be valuable in hybrid breeding programs, while incase of wheat, Genotypes having higher GCA could be used where the selection is performed in subsequent generations. In most of the studies on combining ability, it was found that yield companents are governed by additive and nonadditive gene action. In this study it was observed that yield and concerned yield contributing traits were associated with additive and non additive type gene action, so these genotypes might be exploited through biparental approach in wheat crop, Triticum aestivum.

This experiment concluded that parental genotype, TACUPETO F2001/ BRAMBLING/5/NAC/TH.AC/ /3*PVN/3/ MIRLO was the best general combiners for all examined traits of wheat and HD3159 was the best general combiners for the all examined traits of wheat (Triticum aestivum) except grain yield per plant. If the general combining abilities and the mean values of these genotypes considered, these three parents could be used in hybridization program for the improvement of genotypes towards higher number of grains per spike and 1000 grain weight and harvest index of wheat. On the other hand, if the specific combining abilities and the mean values of the cross combinations are considered, than F1 cross combinations such TACUPETO F2001/ BRAMBLING/5 /NAC/TH.AC/ /3*PVN/3 /MIRLO $\times$ PBW660 and CROC-1/ AE.SQUARROSA $\times$ PBW660 could be effective to improve these traits. The predominance of non-additive type of gene action as well as over-dominant inheritance of these traits in bread wheat, clearly showed that selection in early generation may be useful. Therefore, for the improvement of these traits of wheat, selection of superior plants should be soon through early generations. Information in this regard would help breeders to make better selection of desirable parents to develop an efficient breeding program to obtain new wheat cultivars with high grain yield potential for food and nutritional security. 


\section{References}

Abd El-Aty, M.S.M. and Hamad, S.M. (2006). General and specific combining ability and their interaction with three nitrogen levels for grain yield and related traits in bread wheat (Triticum aestivumL.). $J$. Agric. Sci.Mansoura Univ., 31(9): 5517 5533.

Aida, A.,Rizkalla, Baseta, A., Hussien, A.M.F., Ansary, J.E., Nasseef, Mona andHussien, H.A.(2012). Combining ability and heterosis relative to raped marker in cultivated and newly hexaploid wheat varieties. Aust. J. Basic appl. Sci., 6(5): 215224

Ashraf, S., malook, S., Naseem, I., Ghori, N., Ashraf, S., Qasran, S.A., Khalid, S., khaliq, I. and Amin, W. (2015). Combining ability analysis a breeding approach to develop Drought tolerance of wheat genotypes. Am-Eorous. J. Agric. \&Environ. sci., 15(3): 415423.

Bagiu, A. N. and Nedelea, G. (2013). Combining ability of diallel crosses of winter wheat varieties for spike yield components. J. Hortic. For. Biotech., 17(1): 355-358.

Barot, H.G., Patel, M.S., Sheikh, W.A., Patel, L.P. and Allam, C.R. (2014). Heterosis and combining ability analysis for yield and its component traits in wheat (Triticum aestivum L.). Electr. J. Plant Breed., 5(3): 350359.

Bhutta, M.A., Azhar, S., Chowdhry, M.A. (1997). Combining ability studies for yield and its components in spring wheat (Triticum aestivumL.). Pak.J. Agric. Res., 35: 353-359.

Burungale, S.V., Chauhan, R.M., Gami,R.A.Thakor, D.M. and Patel, P.T. (2011). Combining ability analysis for grain and quality traits in bread Wheat (Triticum aestivumL.). Trends in Bio Science, 4(1): 120-122.

Cifi, E.A. and Yagdi, K. (2010). The research of combining ability of agronomic traits of breed wheat in $\mathrm{F}_{1}$ and $\mathrm{F}_{2}$ generation. $J$.
Agric. Fac. UlvdogUnvi., 24(2): 85-92

Erkul, A., Unay, A. and Konak, C. (2010). Inheritance of yield and yield components in bread wheat (Triticum aestivumL.) cross. Turk. J. Field Crops, 15(2): 137140.

Farooq.M.U., Ishaaq, I., Maqbool, R., Aslam, I., Naqvi, M.T.A. and Mustafa, S.E. (2019). Heritability, genetic gain and detection of gene action in hexaploid wheat for yield and its related attributes. AIIMS agri. and Food, 4(1): 56-52.

Griffing, B. (1956). Concept of general and specific combining ability in relation to diallel crossing system. Aust. J. Biol. Sci., 9: 463-493.

Hayman, B. I. (1954). The theory and analysis of diallel crosses. Genetics, 39: 251-271.

Istipliler, D., Ilker, E., Tonk, F.A., Civi, G. and Tosun, M. (2015). Line $\times$ tester analysis and estimating combining abilities for yield and some yield components in bread wheat.Turk. J. Field Crops., 20(1): 72-77.

Jinks, J.L. and Jones, M.R. (1958). Estimation of the components of heterosis. Genetics, 43(2): 223-234.

Khan, M.A., Ahmad, N., Akbar, M., Rehman, A. and Iqbal, M.M. (2007). Combining ability analysis in wheat. Pak. J. Agri. Sci., 44 (1):1-5.

Kohan, M. Z. and Heidari, B. (2014). Diallel cross study for estimating genetic components underlying wheat grain yield. J. Biol. Environ. Sci., 8(22): 37-51.

Kumar, A., Mishra, V.K., Vyas, R.P. and Singh, V. (2011). Heterosis and combining ability analysis in bread wheat (Triticum aestivumL.).J. Pl. Breed.Crop. Sci., 3(10): 209-217.

Kumar, A., Swati, Kumar,A., Adhikari, S. and Prasad, B. (2018).Genetic Dissection of Wheat Genotypes Using MorphoPhysiological Traits for Terminal Heat Tolerance. Int.J.Curr.Microbiol.App.Sci., 7(2): 367-372.

Kumar, A.H., Kumar, A. and Prasad, B. (2015a). Combining ability and gene interaction study for yield, its attributing traits and quality in common wheat.J. 
App. Nat. Sci., 7(2): 927-934.

Kumar, D., Kerkhi, S.A., Singh, G. and Singh, J. B. (2015b). Estimates of genetic parameters for grain yield, agromorphological traits and quality attributes in bread wheat (Triticum aestivumL.). Indian J. Agr. Sci., 85(5): 622-631.

Ljubičić, N., Petrović, S., Dimitrijević, M., Hristov, N., Vukosavljev, M. and Srećkov, Z. (2014). Diallel analysis for spike length in winter wheat. Turk. J. Agric. Nat. Sci., 2 :1455-1459.

Mandal, A.B. (2016). Combining ability analysis for morphological and yield traits in wheat (Triticum aestivumL.).J. Plant Sci. Res., 3(2): 157-162.

Mather, K. and Jinks, J.L. (1971). Biometrical Genetics. Sec. Ed., Chapman and Hall, London.

Mohamed, M.M. (2007). Study of inheritance of earliness in some wheat crosses. M.SC. Thesis, Fac. of Agric. Minia Univ., Egypt.

Nazir, A., Khaliq, I., Farooq, J., Mahmood, K., Mahmood, A., Hussain, M.M. and Shahid, M. (2014).Pattern of inheritance in some yield related parameters in spring wheat (Triticum aestivumL.). Am. J. Biol. and Life Sci., 2(6): 180-186.

Raj, P. and Kandalkar, V.S. (2013). Combining ability and heterosis analysis for grain yield and its components in wheat. $J$. Wheat Res., 5(1): 45-49.

Roy, D., Deo, I., Kohli, B. and Nagar, K.
(2019). Deciphering the estimates of combining ability and heterosis for yield and quality traits through line $\times$ tester analysis in basmati rice (Oryza sativa L.). Int. J. Chemical Studies, 7(6): 2233-2241.

Seboka, H., Ayana, A. and Zelleke, H. (2009). Combining ability analysis for bread wheat (Triticum aestivumL.). East. Afr. J. Sci., 3(1): 87-94.

Shehzad, M., Hussain, S.B., Qureshi, M.K., Akbar, M., Javed, M., Imran, H.M. and Manzoor, S.A. (2015). Diallel cross analysis of plesiomorphic traits in Triticum aestivumL. Genet. Mol. Res., 14(4): 13485-13495.

Singh, K. and Paroda, R.S. (1986). Partial diallel analysis including parents for combining ability in wheat. Indian J.Geneticsand Plant Breed., 46(3): 490495.

United Nations, Department of Economic and Social Affairs, Population Division, (2018). World Population Prospects: The 2015 Revision, Key Findings and Advance Tables. Working Paper No. ESA/P/WP., 241.

Yao, J., Ma, H., Yang, X. Yao, G. and Zhou, M. (2014). Inheritance of grain yield and its correlation with yield components in bread wheat (Triticum aestivumL.). Afr. J. Agric. Res., 13(12): 1379-1385

\section{How to cite this article:}

Kuldeep Nagar, Swati, Richa Dhyani and Deepayan Roy. 2020. Deciphering the Genetics of Some Important Grain Yield traits in Bread Wheat (Triticum aestivum L. em. Thell). Int.J.Curr.Microbiol.App.Sci. 9(07): 3813-3823. doi: https://doi.org/10.20546/ijcmas.2020.907.446 